\title{
Contamination of Cadmium, Lead, Mercury and Manganese in Leachate from Open Dump, Controlled Dump and Sanitary Landfill Sites in Rural Thailand: A Case Study in Sakon Nakhon Province
}

\author{
K. Ruengruehan*, R. Junggoth**, S. Suttibak***, C. Sirikoon**** and N. Sanphoti*† \\ *Department of Community Health Faculty of Public Health, Kasetsart University, Chalermphrakiat Sakon Nakhon \\ Province Campus, Thailand \\ **Department of Environmental Health Occupational Health and Safety, Faculty of Public Health, Khon Kaen \\ University, Thailand \\ ***Department of Civil Engineering, Faculty of Science and Engineering, Kasetsart University, Chalermphrakiat Sakon \\ Nakhon Province Campus, Thailand \\ ****Senior-Professional Environmental Officer, Sakon Nakhon Provincial Offices for Natural Resources and \\ Environment, Thailand
}

†Corresponding author: N. Sanphoti; nirawan.s@ku.th

Nat. Env. \& Poll. Tech.

Website: www.neptjournal.com

Received: $27-07-2020$

Revised: $15-09-2020$

Accepted: 01-11-2020

\section{Key Words:}

Heavy metals

Open dump

Controlled dump

Sanitary landfill

\begin{abstract}
The contamination of heavy metal in leachate was investigated at various sites with different solid waste management, namely an open dump, controlled dump, and sanitary landfill. The results indicated that all four heavy metals investigated (cadmium, lead, mercury, and manganese) were present in the leachate at all solid waste management sites. The highest cadmium and lead concentrations were each observed in open dump leachate samples, while the highest manganese and mercury concentrations were each observed in controlled dump leachate samples.
\end{abstract}

\section{INTRODUCTION}

Currently, population growth in Thailand is causing a huge demand for basic living factors, and consequently, many problems stem from the utilization of many kinds of products, with many unused materials resulting in a huge amount of solid waste. In addition, waste products from daily consumption such as plastic foam boxes and food waste are increasing every day, and these are contributing further to increased waste management problems. There are various methods of waste management such as incineration of solid waste, landfill waste, or the use of 3R (reuse, recycling, reduce) practices (Chiemchaisri et al. 2007), with the method used depending on the municipality. Many government agencies in Thailand have different methods of waste management (sanitation landfill and improper landfill to deal with the waste problem) (Chinnathan et al. 2017, Muttamara et al. 2017). However, local government in many areas still lack the budget and knowledgeable staff to manage solid waste disposal. Local administrative organizations in Sakon Nakhon province have chosen to use three different methods of management: open dump, controlled-open dump, and sanitary landfill. Although the forms of waste disposal are different, all of them face the same problem of leachate contaminating the environment. Leachate is the water caused by waste degradation by microorganisms and it can permeate through the waste pile and dissolve various contaminants into the soil in the form of a solution mixed with suspended solids and sediment (Xaypanya et al. 2018). External water sources, such as rainwater, can enter the waste and these contribute to the leachate. Leachate often has a high concentration of pollutants such as COD, heavy metals, and various kinds of organic substances. Contamination in sampled water may vary due to the humidity, rainfall, waste composition, and season (Ogundiran \& Afolabi 2008). Compared with water generally, leachate is very dirty and can pollute and deteriorate the soil through which it passes, making the soil unsuitable for plant growth which affects, directly and indirectly, human health and other organisms in the ecosystem (Kanmani \& Gandhimathi 2013). Heavy metal contamination, especially in potable water supplies makes 
the water unsuitable for human use (Fauziah et al. 2013). The leachate normally consists of pathogens, solutions, suspensions, and various contaminants, especially, toxic heavy metals (Chiemchaisri et al. 2015). A study of heavy metal contamination in the leachate at the On Nut Waste Disposal Facility, Bangkok, Thailand reported that the contamination levels of mercury, manganese, and cadmium were in the ranges 2.4-39.1 mg.L $\mathrm{L}^{-1}, 0.01-2.88 \mathrm{mg} . \mathrm{L}^{-1}$, and 0.008-0.013 mg. $\mathrm{L}^{-1}$ respectively (Thapanandana 1993). However, there has been less research on heavy metal contamination in various types of solid waste management in rural areas. Thus, the current study investigated the contamination of cadmium, lead, mercury, and manganese in leachate under various types of solid waste management, namely open dump, controlled dump, and sanitary landfill in the rural area of Sakon Nakhon municipality, Thailand.

\section{MATERIALS AND METHODS}

Cross-sectional research was used to investigate the contamination of heavy metals in leachate under various types of solid waste management. Cadmium, lead, mercury, and manganese were chosen as representative heavy metals in the leachate. The methodology of this study was separated into two parts: 1) the collection and survey of municipal waste landfill sites and 2) sampling of heavy metals in leachate under various types of solid waste management. Groundwater samples were taken from an observed well using Bailer and Peristaltic pumps. To reduce sampling error, water sampling was carried out after pumping had drained some water until the acid-alkali value, electrical conductivity, and temperature of the water sampled in the well were constant. A polyethylene or polypropylene pipe was inserted into the well to the desired depth. Then water was pumped up to the ground and the sample was treated by adding $\mathrm{HNO}_{3}$ solution to lower the $\mathrm{pH}$ level to less than or equal to $\mathrm{pH} 2$ before analysis in the laboratory. The surface water sampling process was achieved by grab sampling to collect the sample at a specified time, and then the sample was treated by adding $\mathrm{HNO}_{3}$ solution to reduce to $\mathrm{pH} 2$. An atomic absorption spectrophotometer (Perkin Elmer; Model A, Analyst 100; USA) was used for the heavy metal analysis.

\section{RESULTS AND DISCUSSION}

\section{Sanitary Landfill Disposal Site}

Three sanitary landfill sites were identified in Sakon Nakorn, namely in Tha Rae, Sakon Nakhon subdistrict, and Phang Khon subdistrict. Tha Rae subdistrict municipality had a landfill area of $48,000.0 \mathrm{~m}^{2}$, with $12.9 \mathrm{t} /$ day of community waste entering the landfill system and the amount of community waste accumulated was 5.46 t. The landfill was surrounded by a fence; however, there was a problem due to people scavenging waste from the area. The Sakon Nakhon municipality had a landfill waste area of $260,000.0 \mathrm{~m}^{2}$, with $66.89 \mathrm{t} /$ day of community waste entering the landfill system and the amount of community waste accumulated was 42.5 t. The solid waste landfill site in Phang Khon subdistrict municipality had a landfill area of 78,400.0 $\mathrm{m}^{2}$ based on sanitary landfill. The amount of solid waste entering the landfill system was $29.7 \mathrm{t} /$ day and the amount of accumulated waste was $25.2 \mathrm{t}$. The details are provided in Table 1 .

\section{Controlled Dumpsite}

The disposal site in Dong Mafai municipality was 35,200.0 $\mathrm{m}^{2}$ in size and the amount of waste entering the disposal site was $19.0 \mathrm{t} /$ day and the amount of accumulated waste in the system was $5.4 \mathrm{t}$. The site was completely fenced with gates for access. There was no incineration of waste. Behind the site, a wall had been built with some trees as a buffer and to prevent waste scavenging. The solid waste site in Nong Lat subdistrict municipality had an area of $6,400.0 \mathrm{~m}^{2}$, with 10.2 t/day of solid waste entering the system and the amount of accumulated waste in the system was $3.5 \mathrm{t}$. Solid waste was open-dumped and then incinerated behind a wall. In addition, there was an area for dumping garbage and incineration outside the wall behind the incinerator. The solid waste site in Sawang Daen Din sub-district municipality had an area of $51,200.0 \mathrm{~m}^{2}$. The amount of municipal solid waste was $19.0 \mathrm{t} /$ day and the amount of accumulated waste was 312.0 t. There was open dumping, plowing of old solid waste, and modifying the area for new solid waste, but no burning of solid waste. There was no perimeter fence with gates nor a buffer, so there was a problem with scavenging by people.

Table 1: Information on sanitary landfill sites.

\begin{tabular}{|c|c|c|c|c|c|c|}
\hline \multirow{2}{*}{$\begin{array}{l}\text { Type of solid waste } \\
\text { management }\end{array}$} & \multirow[t]{2}{*}{ Location Name } & \multicolumn{2}{|c|}{ Location of site } & \multirow{2}{*}{$\begin{array}{l}\text { Landfill size } \\
\left(\mathrm{m}^{2}\right)\end{array}$} & \multirow{2}{*}{$\begin{array}{l}\text { Solid waste } \\
\text { (t/day) }\end{array}$} & \multirow{2}{*}{$\begin{array}{l}\text { Accumulated solid } \\
\text { waste }(\mathrm{t})\end{array}$} \\
\hline & & Latitude & Longitude & & & \\
\hline \multirow[t]{3}{*}{ Sanitary landfill } & Tha Rae & 17.29288 & 104.22897 & 48,000 & 12.9 & 5.4 \\
\hline & Sakon Nakhon & 17.06875 & 104.18266 & 260,000 & 66.8 & 42.5 \\
\hline & Phang Khon & 17.39227 & 103.73387 & 78,400 & 29.7 & 25.2 \\
\hline
\end{tabular}


The solid waste site in Wanon Niwat municipality had an area of 11,200.0 $\mathrm{m}^{2}$. The amount of solid waste delivered to the site was $10.5 \mathrm{t} /$ day and there was $120.0 \mathrm{t}$ of accumulated waste. There was open dumping and burning around the entrance area. The details for these sites are provided in Table 2 .

\section{Uncontrolled Dumpsite}

The disposal system in the Bong Tai sub-district municipality had an area of $43,200.0 \mathrm{~m}^{2}$. The amount of solid waste delivered to the site system was $5.0 \mathrm{t} /$ day and the amount of accumulated solid waste was 63.0 t. There was open dumping and burning of solid waste. There was no gate but there was a wire fence with some trees as a buffer and there was a moat around the area. There was no plowing of old solid waste. The waste disposal site in the Nong Luang sub-district municipality had an area of $8,000.0 \mathrm{~m}^{2}$. The amount of solid waste delivered to the site was $0.5 \mathrm{t} /$ day and the amount of accumulated waste was 22.5 t. Plowing, spreading, and landfilling occurred. The waste site in Song Dao municipality had a landfill area of $9,600.0 \mathrm{~m}^{2}$. The amount of solid waste delivered to the site was $4.0 \mathrm{t} /$ day and the amount of accumulated waste in the area was 30.0 t. No incineration was evident. The site had gates and a perimeter wire fence, so there was no evidence of scavenging. The disposal system in Ban Phon sub-district municipality had an area of 3,200.0 $\mathrm{m}^{2}$. The amount of solid waste delivered to the site was 0.60 $\mathrm{t} / \mathrm{day}$ and the amount of accumulated waste was $3.6 \mathrm{t}$. There was waste burning but there were no gates or a fence and no solid waste collection service (villagers dumped their waste themselves). The solid waste site in the Kut Bak sub-district municipality had an area of $6,720.0 \mathrm{~m}^{2}$. The amount of waste delivered to the site was $0.92 \mathrm{t} /$ day and the amount of accumulated waste was 68.0 t. There was no landfilling using the old waste. The site was gated and fenced and located near the community. A sewage fermentation tank was located in the same area. The details for these sites are provided in Table 3 .

\section{Contamination of Heavy Metal in Leachate}

The analysis considered the contamination of cadmium, lead, mercury, and manganese in the leachate of municipalities with a sanitary landfill in three subdistrict municipalities, namely Tha Rae, Sakon Nakhon, and Phang Khon. The results indicated the leachate samples had $\mathrm{pH}$ values in the range 6.8-8.7 and electrical conductivity in the range 4.5$8.6 \mu \mathrm{s} / \mathrm{cm}$. The conductivity of the leachate in Phang Khon subdistrict municipality was quite high at $4,499.0 \mu \mathrm{s} / \mathrm{cm}$. The leachate temperature was in the range $27.5-33.0^{\circ} \mathrm{C}$ and turbidity was in the range 14.5-185.0 NTU (Table 4). The concentrations of cadmium, lead, mercury, and manganese were in the ranges of $0.01-0.24,0.01-0.12,0.02-0.12$, and 0.18-0.76 mg. $\mathrm{L}^{-1}$ respectively (Table 5). For the controlled dumps (Dong Mafai, Nong Lat, Sawang Daen Din, and Wanon Niwat subdistrict municipalities), the leachate samples had $\mathrm{pH}$ values in the range 4.7-8.3, electrical conductivity in the range $8.30-4341.0 \mu \mathrm{s} / \mathrm{cm}$, temperature in the range 28.2-33. ${ }^{\circ} \mathrm{C}$, and turbidity in the range 8.2-340.0 NTU (Table $4)$. The concentrations of cadmium, lead, mercury, and manganese were in the ranges $0.20-0.48,0.21-0.35,0.12-1.22$, and $0.26-1.89 \mathrm{mg} . \mathrm{L}^{-1}$ respectively (Table 5). The cadmium, lead, mercury, and manganese concentrations were analyzed

Table 2: Information on controlled dumpsites.

\begin{tabular}{|c|c|c|c|c|c|c|}
\hline \multirow{2}{*}{$\begin{array}{l}\text { Type of solid waste } \\
\text { management }\end{array}$} & \multirow[t]{2}{*}{ Location name } & \multicolumn{2}{|c|}{ Location of site } & \multirow{2}{*}{$\begin{array}{l}\text { Landfill size } \\
\left(\mathrm{m}^{2}\right)\end{array}$} & \multirow{2}{*}{$\begin{array}{l}\text { Solid waste } \\
\text { (t/day) }\end{array}$} & \multirow{2}{*}{$\begin{array}{l}\text { Accumulated solid } \\
\text { waste }(\mathrm{t})\end{array}$} \\
\hline & & Latitude & Longitude & & & \\
\hline \multirow[t]{4}{*}{ Controlled dump } & Dong Mafai & 17.29876 & 104.04488 & 35,200 & 19.0 & 5.4 \\
\hline & Nong Lat & 17.31089 & 103.59319 & 6,400 & 10.2 & 3.2 \\
\hline & Sawang Daen Din & 17.50000 & 103.46523 & 51,200 & 32.0 & 312.0 \\
\hline & Wanon Niwat & 17.62784 & 103.75658 & 11,200 & 10.5 & 120.0 \\
\hline
\end{tabular}

Table 3: Information on uncontrolled dumpsites.

\begin{tabular}{|c|c|c|c|c|c|c|}
\hline \multirow[t]{2}{*}{ Type of solid waste management } & \multirow[t]{2}{*}{ Location name } & \multicolumn{2}{|c|}{ Location of site } & \multirow{2}{*}{$\begin{array}{l}\text { Landfill size } \\
\left(\mathrm{m}^{2}\right)\end{array}$} & \multirow{2}{*}{$\begin{array}{l}\text { Solid waste } \\
\text { (t/day) }\end{array}$} & \multirow{2}{*}{$\begin{array}{l}\text { Accumulated } \\
\text { solid waste }(\mathrm{t})\end{array}$} \\
\hline & & Latitude & Longitude & & & \\
\hline \multirow[t]{5}{*}{ Open dump } & Bong Tai & 17.41993 & 103.30216 & 43,200 & 5.0 & 63.0 \\
\hline & Nong Luang & 17.40499 & 103.38456 & 8,000 & 0.5 & 22.5 \\
\hline & Song Dao & 17.35378 & 103.48229 & 9,600 & 4.0 & 30.0 \\
\hline & Ban Phon & 17.24517 & 103.82255 & 3,200 & 0.6 & 3.6 \\
\hline & Kut Bak & 17.08435 & 103.82255 & 6,720 & 9.2 & 68.0 \\
\hline
\end{tabular}


in the leachate from five subdistrict municipalities with open dumpsites (Bong Tai, Nong Luang, Song Dao, Phon Na Kaeo, and Kut Bak). The leachate samples had $\mathrm{pH}$ values in the range 6.5-7.6, electrical conductivity in the range 4.5-2461.0 $\mu \mathrm{s} / \mathrm{cm}$, temperature in the range $22.8-33.0^{\circ} \mathrm{C}$, and turbidity in the range 21.2-1033.0 NTU (Table 4). The concentrations of cadmium, lead, mercury, and manganese were in the ranges $0.01-1.25,0.02-1.25,0.17-0.57$, and $0.21-0.46 \mathrm{mg}^{-\mathrm{L}^{-1}}$ respectively (Table 5).

\section{CONCLUSION}

The contamination of heavy metal in leachate was investigated at different dumpsites (sanitary landfill, controlled dump, and open dump) by sampling for cadmium, lead, mercury, and manganese in municipal waste leachate and comparing the concentrations. The results indicated that the heavy metals were present in the leachate from all types of solid waste management.

(a) The highest cadmium concentration was observed in the open dump leachate, followed by controlled dump leachate, and sanitary landfill leachate.

(b) The highest lead concentration was observed in the open dump leachate, followed by controlled dump leachate, and sanitary landfill leachate.

(c) The highest manganese concentration was observed in the controlled dump leachate, followed by open dump leachate, and sanitary landfill leachate.

Table 4: $\mathrm{pH}$, conductivity, temperature, and turbidity of leachate from different sites.

\begin{tabular}{|c|c|c|c|c|c|}
\hline Type of solid waste management & Location name & $\mathrm{pH}$ & Conductivity, $\mathrm{mS} . \mathrm{c}^{-1}$ & Temperature & Turbidity, NTU \\
\hline \multirow[t]{3}{*}{ Sanitary landfill } & Tha Rae & 7.6 & 4.5 & 27.5 & 131.0 \\
\hline & Sakon Nakhon & 8.7 & 8.6 & 29.5 & 185.0 \\
\hline & Phang Khon & 6.8 & $4,499.0$ & 33.0 & 14.5 \\
\hline \multirow[t]{4}{*}{ Controlled dump } & Dong Mafai & 8.3 & 8.3 & 28.9 & 8.4 \\
\hline & Nong Lat & 4.7 & 64.6 & 28.2 & 8.2 \\
\hline & Sawang Daen Din & 7.1 & $2,413.0$ & 30.0 & 184.0 \\
\hline & Wanon Niwat & 7.0 & $4,341.0$ & 33.0 & 340.0 \\
\hline \multirow[t]{5}{*}{ Open dump } & Bong Tai & 7.2 & 962.0 & 33.0 & 438.0 \\
\hline & Nong Luang & 6.5 & $2,461.0$ & 33.0 & 1033.0 \\
\hline & Song Dao & 6.9 & $1,005.0$ & 31.0 & 347.0 \\
\hline & Ban Phon & 6.8 & 320.0 & 22.8 & 21.2 \\
\hline & Kut Bak & 7.6 & 4.5 & 27.5 & 131.0 \\
\hline
\end{tabular}

Table 5: Concentration of heavy metals $(\mathrm{Cd}, \mathrm{Pb}, \mathrm{Mn}, \mathrm{Hg})$ in leachate.

\begin{tabular}{|c|c|c|c|c|c|}
\hline Type of solid waste management & Location name & $\mathrm{Cd}\left(\mathrm{mg} . \mathrm{L}^{-1}\right)$ & $\mathrm{Pb}\left(\mathrm{mg} \cdot \mathrm{L}^{-1}\right)$ & $\mathrm{Mn}\left(\mathrm{mg} . \mathrm{L}^{-1}\right)$ & $\mathrm{Hg}\left(\mathrm{mg} \cdot \mathrm{L}^{-1}\right)$ \\
\hline \multirow[t]{3}{*}{ Sanitary landfill } & Tha Rae & 0.01 & 0.01 & 0.18 & 0.02 \\
\hline & Sakon Nakhon & 0.24 & 0.12 & 0.25 & 0.04 \\
\hline & Phang Khon & 0.02 & 0.02 & 0.76 & 0.12 \\
\hline \multirow[t]{4}{*}{ Controlled dump } & Dong Mafai & 0.35 & 0.21 & 0.26 & 0.12 \\
\hline & Nong Lat & 0.48 & 0.25 & 0.93 & 1.22 \\
\hline & Sawang Daen Din & 0.20 & 0.35 & 1.89 & 0.25 \\
\hline & Wanon Niwat & 0.21 & 0.32 & 1.53 & 0.14 \\
\hline \multirow[t]{5}{*}{ Open dump } & Bong Tai & 0.02 & 0.15 & 0.43 & 0.18 \\
\hline & Nong Luang & 0.01 & 0.02 & 0.47 & 0.21 \\
\hline & Song Dao & 0.21 & 0.45 & 0.46 & 0.17 \\
\hline & Ban Phon & 0.04 & 1.25 & 0.21 & 0.57 \\
\hline & Kut Bak & 1.25 & 0.87 & 0.41 & 0.28 \\
\hline
\end{tabular}


(d) The highest mercury concentration was observed in the controlled dump leachate, followed by open dump leachate, and sanitary landfill leachate.

\section{REFERENCES}

Chiemchaisri, C., Juanga J.P. and Visvanathan, C. 2007. Municipal solid waste management in Thailand, and disposal emission inventory. Environ. Monit. Assess., 135(1-3): 13-20.

Chiemchaisri, C., Chiemchaisri, W. and Witthayapirom, C. 2015. Remediation of MSW landfill leachate by a permeable reactive barrier with vegetation. Water Sci. Technol., 71(9): 1389-1397.

Chinnathan, A., Jarudej, A., Supachot, S., Jeerattikul, K., Bundit, I., Phatavee, P., Chanoknunt, K., Wichai, S. and Chiemchaisri, C. 2017. Municipal plastic waste composition study at transfer station of Bangkok and possibility of its energy recovery by pyrolysis. Energy Procedia, 107: $222-226$.

Fauziah, S.H., Izzati, M.N. and Agamuthu, P. 2013. Toxicity on Anabas
Testudineus: A case study of sanitary landfill leachate. Procedia Environ. Sci., 18: 14-19.

Kanmani, S. and Gandhimathi, R. 2013. Assessment of heavy metal contamination in soil due to leachate migration from an open dumping site. Appl. Water Sci., 3: 193-205.

Muttamara, S., Visvanathan, C. and Alwis, K.U. 1994. Solid waste recycling and reuse in Bangkok. Waste Manag. Res., 12(2): 151-163.

Ogundiran, O.O. and Afolabi, T.A. 2008. Assessment of the physicochemical parameters and heavy metals toxicity of leachates from the municipal solid waste open dumpsite. Int. J Environ. Sci. Technol., 5(2): 243-250.

Thapanandana, T. 1993. The contamination of mercury, cadmium, and manganese in leachate from solid waste disposal sites of Bangkok metropolitan administration. Thesis (M.Sc.), Chulalongkorn University, Bangkok, Thailand.

Xaypanya, P., Takemura, J., Chiemchaisri, C., Seingheng, H. and Tanchuling, M. 2018. Characterization of landfill leachates and sediments in major cities of Indochina peninsular countries: Heavy metal partitioning in municipal solid waste leachate. Environment, 5(6): 65. 